\title{
MULTIMEDIA SEBAGAI MEDIA ANALISA TINGKAT KESIAPAN CALON WISUDAWAN UNTUK MEMASUKI DUNIA KERJA RUANG LINGKUP PERBANKAN SYARIAH
}

\author{
Aulia Fitrul Hadi ${ }^{1}$, Pradani Ayu Widya Purnama ${ }^{2}$, Sepsa Nur Rahman ${ }^{3}$ \\ Universitas Putra Indonesia YPTK Padang \\ Email: ${ }^{1}$ fitrulhadi@upiyptk.ac.id, \\ Email: ${ }^{2}$ pradaniayu@gmail.com \\ Email: ${ }^{3}$ sepsanurrahman@gmail.com
}

\begin{abstract}
Abstrak
Penerimaan karyawan pada dunia perbankan penuh dengan permasalahan. Mulai dari perbedaan latar belakang, ketidaksamaan pengetahuan, buta akan dunia kerja dan berbagai macam hal lainnya. Hal tersebut bisa diatasi dengan menggunakan teknologi. Salah satunya adalah teknologi multimedia. Dengan menggunakan multimedia, calon karyawan akan disuguhi dengan pengetahuan dasar akan perbankan yaitu berupa video, animasi, gambar dan suara. Penyajian ini membuktikan $80 \%$ mampu meningkatkan kualitas dari calon karyawan yang diuji. Dengan hasil ini pihak pengembangan sumber daya manusia (HRD) pada perusahaan dapat merekomendasikan calon karyawan yang tepat pada pimpinan perusahaan.
\end{abstract}

Kata kunci: Multimedia, Perbankan, Teknologi, Informasi, Edukasi

\section{Pendahuluan}

Multimedia berasal dari teater, yaitu pertunjukan yang memanfaatkan lebih dari satu medium di panggung yang mencakup monitor video, synthesized band, dan karya seni manusia sebagai bagian dari pertunjukan. Pengertian kedua mensyaratkan adanya sinkronisasi berbagai media tadi dengan bantuan komputer, Membedakkan dengan pengertian multimedia yang pertama yang memanfaatkan berbagai media yang terpisah dan berdiri sendiri (Rizqi, Reno dan Andre, 2015) Multimedia adalah kombinasi dari komputer dan vidio atau secara umum merupakankombinasi tiga elemen yaitu suara, gambar, dan teks atau kombinasu dari yang sedikit dua media input atau output dari data yang berupa audio (suara dan musik). Multimedia yang dimaksud dalam penelitian ini adalah suatu media untuk menyampaikan pengetahuan tentang bagaimana pelayanan atau cara kerja di bank syariah yang merupakan penggabungan dari beberapa unsur yaitu, teks, grafik dan animasi yang digabungkan kedalam media presentasi berupa mickrosoft power point dan kemudian diproyeksikan ke layar monitor dan layar lebar melalui Overhead Projector (infocus) kepada para lulusan perguruan tinggi.[1]

Pada saat ini, tingkat persaingan dunia kerja dirasakan semakin ketat. Dimana dunia kerja ini penganggurannya terus bertambah setiap tahun, khususnya pengangguran dari lulusan perguruan tinggi. Oleh karena itu, para calon sarjana dituntut untuk lebih kreatif, inovatif, memiliki kompetensi, keterampilan kerja, dan kepribadian yang baik. Hal ini karena, lowongan yang tersedia sebenarnya yang menjadi kendala utama bagi seorang sarjana untuk mendapatkan pekerjaan adalah kesiapan mereka untuk bekerja.Dalam hal ini kesiapan kerja para lulusan perguruan tinggi di bank syariah[2]

\section{Tinjauan Literatur}

\subsection{Mendefinisikan Ruang Lingkup Masalah}

$\begin{array}{ll}\text { Dikirim } & : 2018-11-15 \\ \text { Diterima } & : 2018-12-10 \\ \text { Diterbitkan } & : 2018-12-13\end{array}$


Ruang masalah yang akan diteliti harus ditentukan terlebih dahulu, karena tanpa mampu mendefinisikan serta menentukan batasan masalah yang akan diteliti, maka tidak akan didapat suatu solusi yang terbaik dari masalah tersebut.[3]

i. Kondisi kesiapan lulusan perguruan tinggi saat ini hanya terpaku dengan kegiatan yang ada disekitar ruang lingkup pendidikan yang mereka terima di kampus.

ii. Sistem rekruitmen dan pelatihan dalam bidang perbankan syariah saat ini mencakup seberapa jauh pengetahuan calon karyawan atau karyawan pada perusahaan tersebut mengenal kegiatan kerja pada sektor usaha mereka da untuk karyawan perlu diadakan evaluasi semester untuk meningkatkan kualias kerja dari karyawan tersebut.

iii. Teknologi multemedia membantu lulusan perguruan tinggi untuk mengetahui bagaimana kegiatan pada dunia kerja khususnya di perbankan syariah secara umum, sehingga menjadi modal bagi lulusan pada saat seleksi penerimaan calon karyawan pada perbankan syariah tersebut.

\subsection{Analisis Masalah}

Langkah analisis masalah adalah untuk dapat memahami masalah yang telah ditentukan ruang lingkup dan batasan pada pengimplementasian multimedia dengan menggunakan macro media flash 8. Dengan menganalisa masalah yang telah ditentukan tersebut, maka diharapkan masalah yang dipahami dengan baik dan benar, sesuai dengan pemecahan yang diharapkan.

\subsection{Menentukan Tujuan}

Berdasarkan pemahaman dari masalah, maka ditentukan tujuan yang akan dicapai dari penelitian.

i. Membuat Aplikasi multimedia untuk kesiapan kerja lebih menarik, tidak membosankan, tidak ketinggalan jaman dan bermanfaat bagi para lulusan perguruan tinggi dan khususnya bagi BANK SYARIAH.

ii. Melakukan gerakan gogreen atau ramah lingkungan.

iii. Memberikan penilaian secara cepat, akurat terhadap mutu kerja karyawan perbankan syariah tersebut

\section{Metodologi}

Kerangka kerja ini merupakan langkah-langkah yang akan dilakukan dalam rangka penyelesaian masalah yang akan dibahas, seperti gambar 4.1 :

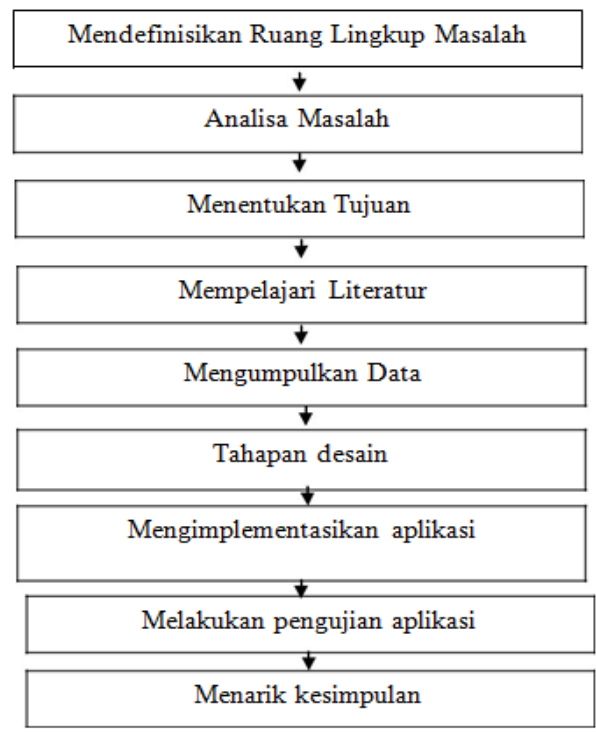




\section{Gambar 1. Kerangka Kerja dalam Penelitian}

\section{Hasil dan Diskusi}

Multimedia adalah penggunaan beberapa media yang berbeda untuk menyampaikan dan menyampaikan informasi dalam bentuk teks, audio, grafik, animasi, dan video. Sistem Multimedia adalah sistem yang dapat digunakan secara digital, transmisi dan representasi beberapa media diskrit (digital) berupa teks, grafik, citra, audio dan video melalui komputer. (elynkusuma,2012)

\section{a. Tipe dari Sistem Multimedia}

1. informasi / data bukan merupakan fungsi waktu

2. Teks

3. Grafik (grafik komputer)

4. Citra (foto)

5. Informasi atau data merupakan fungsi waktu yang harus ditampilkan ke tepat pada titik waktu yang tepat

6. Audio

7. Video

8. Animasi (grafik komputer)

\section{b. Rancangan Sistem Multimedia}

Aplikasi ini dibangun menggunakan macromedia flash 8 dan php mysql. Pada tahap perancangan ini penulis merancang beberapa bagian tahapan. Yang pertama interface dari aplikasi pada saat dijalankan

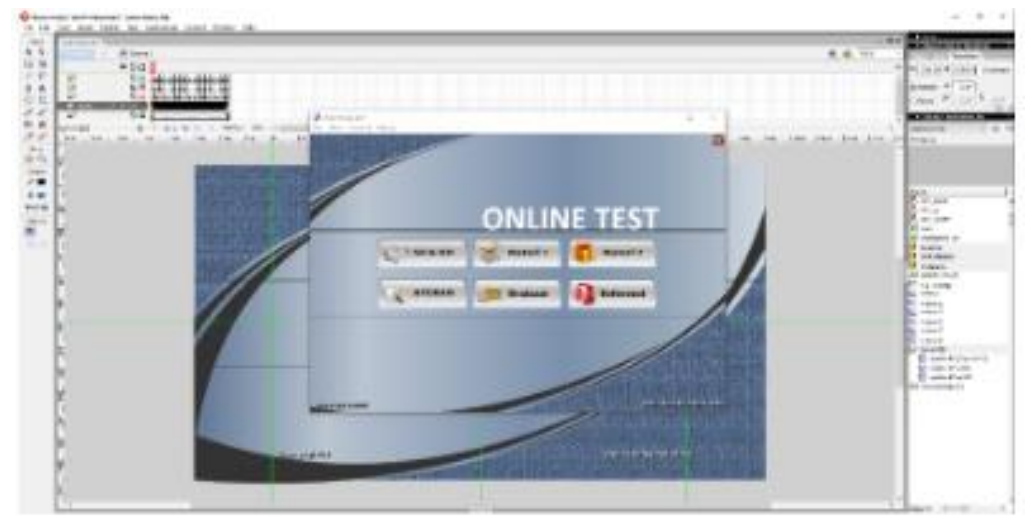

\section{Gambar 2. Rancangan Tampilan Awal}

Ini adalah rancangan awal pembangunan sistem. Tersedia beraneka ragam menu dan pilihan serta petunjuk. 


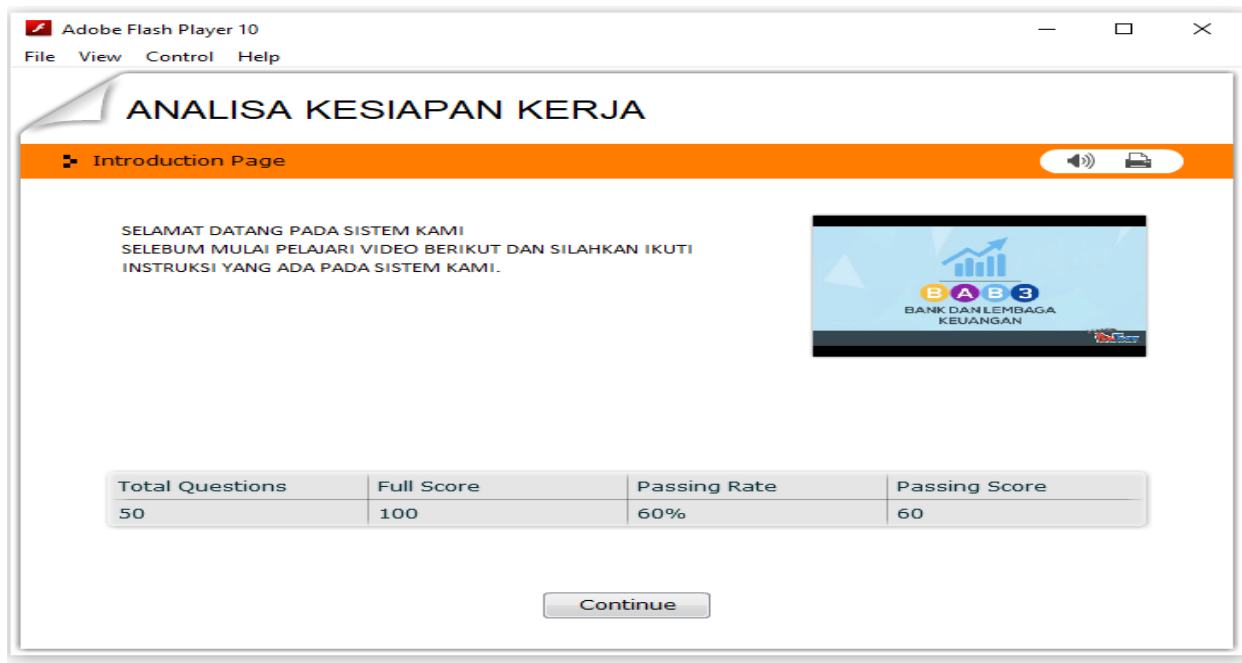

\section{Gambar 3. Menu Utama}

Pada halaman ini peserta bisa mempelajari sekilas tentang perbankan. Di halaman ini disediakan beraneka ragam visual tentang kegiatan perbankan syariah. Setelah peserta selesai, peserta akan melanjutkan ketahap ujian.

\section{c. Halaman Ujian}

Berisi tentang halaman yang menyuduhkan tampilan menu untuk memulai test

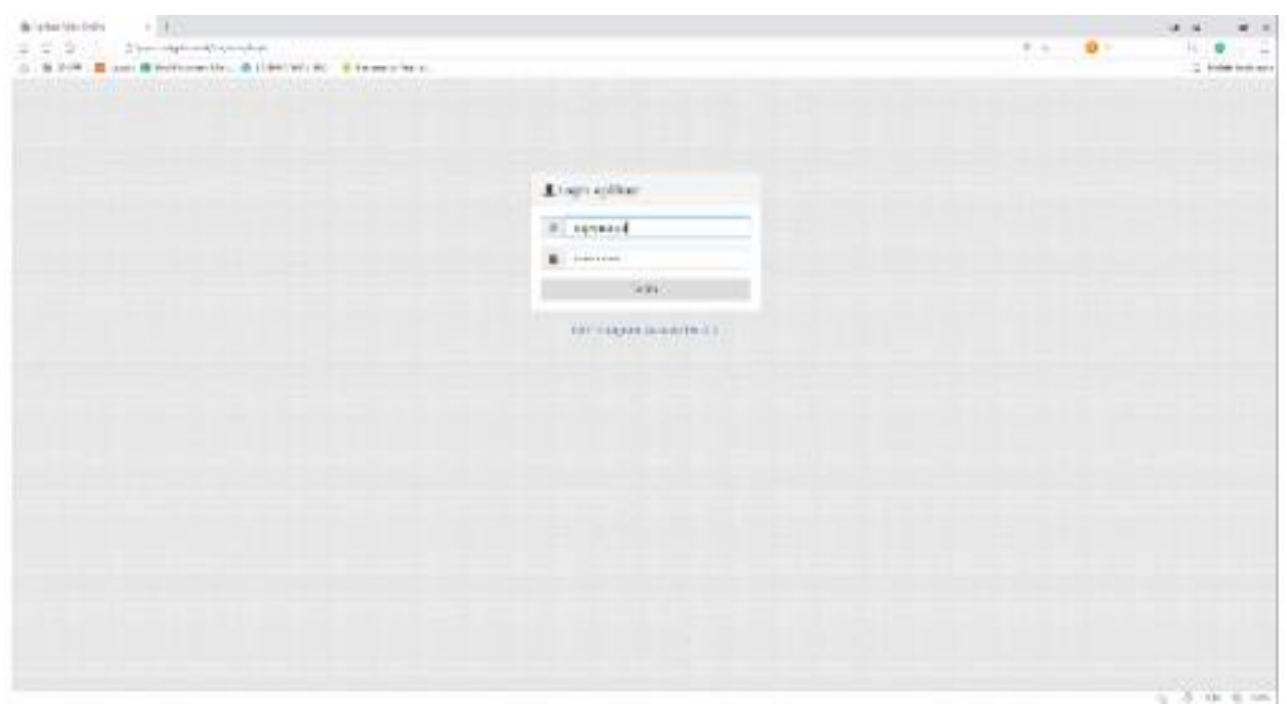

\section{Gambar 4. Halaman Test}

Peserta ujian akan mendapatkan username dan password setelah melamar sebagai calon karyawan . 


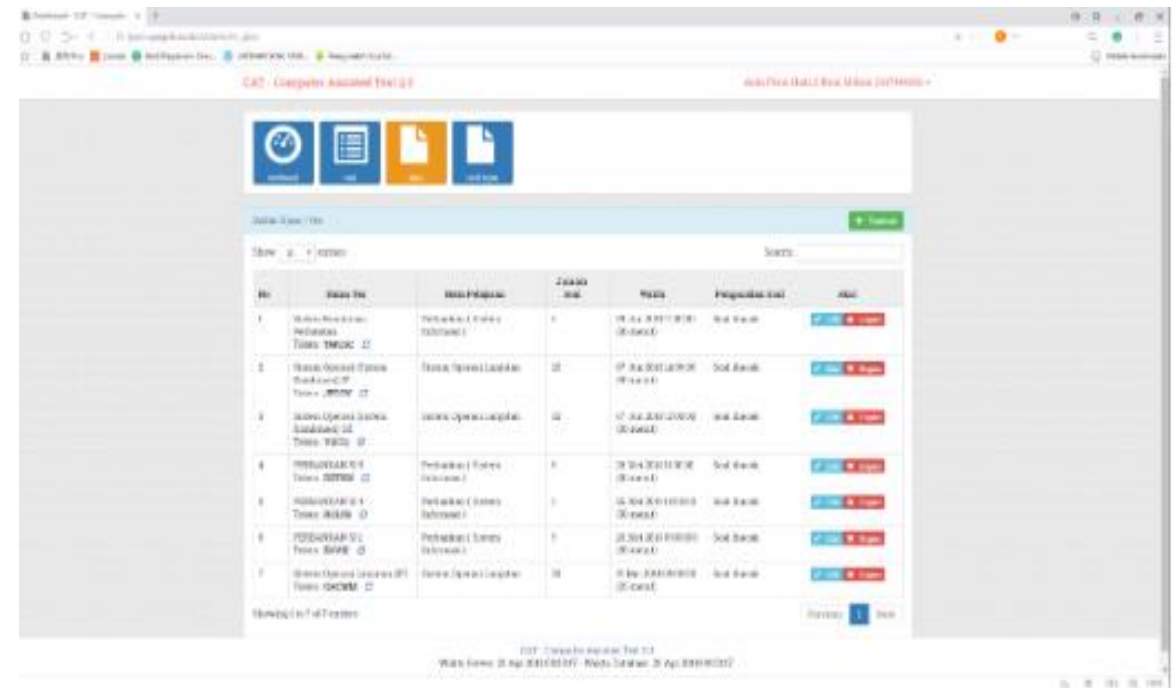

Gambar 5.Tampilan Ujian

Setelah itu peserta akan di suguhkan dengan tes yang ada. Dan akan di persilahkan untuk melaksanakan tes tersebut.

\section{d. Halaman Hasil Ujian}

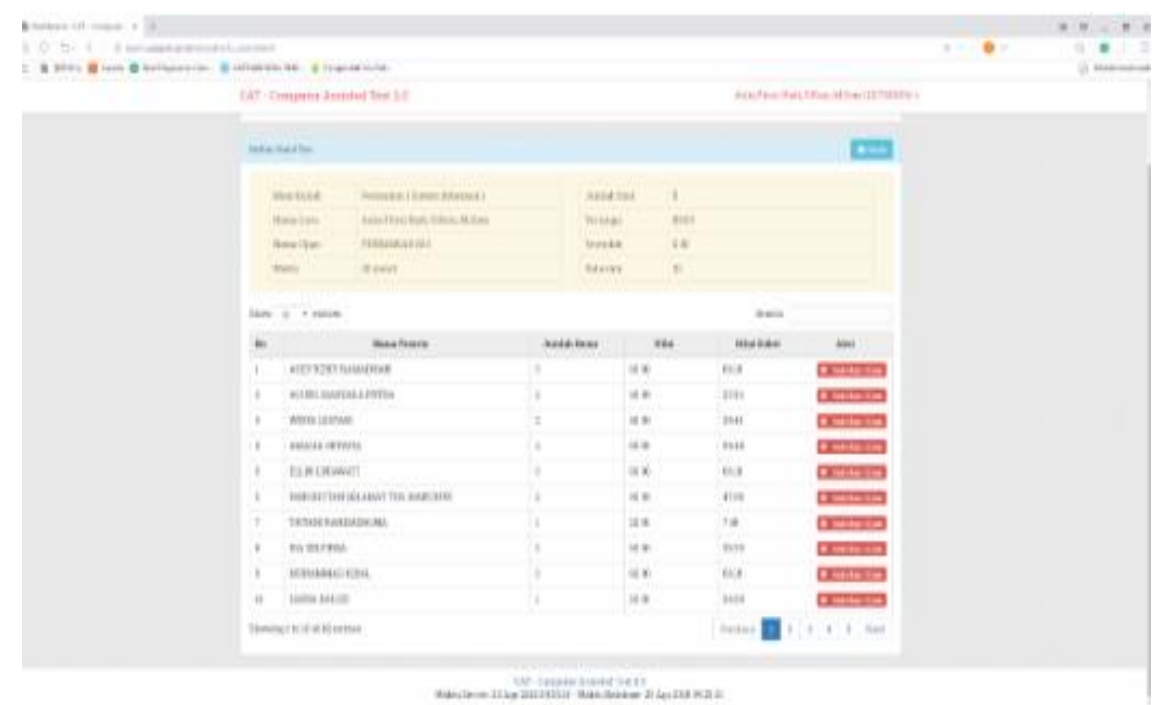

Gambar 6. Hasil Ujian

HRD akan memperoleh data hasil ujian yang telah dilaksanakan oleh calon karyawan beserta rekap nilainya. Hasil ujian akan di cetak dan diserahkan kepada pimpinan untuk diseleksi memasuki tahap wawancara.

\section{e. Analisa Hasil Ujian}

Hasil ujian yang telah dilewati dan diselesaikan oleh user dianalisa menggunakan rumus (R1+R2)/2. Misalkan nilai ujian 1 ditambah dengan nilai ujian ke 2 baru dibagi 2 sehingga didapatkan nilai rerata untuk kedua ujian tersebut.

\section{Kesimpulan}

Pengembangan animasi yang akan dilakukan ialah dengan memberikan tutorial atau edukasi tentang dunia kerja perbankan syariah. Pada tahapan ini sistem akan disuguhkan dengan beberapa video 
yang menjelaskan tentang pekerjaan yang ada diperbankan syariah. Video akan mengedukasi tentang materi yang akan di uji pada halaman ujian. Sehingga sistem multimedia ini dapat membantu perbankan untuk mendapatkan calon tenaga kerja yang lebih kompeten di bidangnya

\section{Referensi}

[1] Hadi, A. F., Purnama, P. A. W., \& Rahman, S. N. (2018, November). Pembangunan Aplikasi Multimedia Sebagai Media Analisa Kesiapan Kerja Lulusan Perguruan Tinggi Pada Sektor Perbankan Syariah. In Seminar Nasional Teknologi Informasi Komunikasi dan Industri.

[2] Moore, R., Lopes, J., 1999. Paper templates. In TEMPLATE'06, 1st International Conference on

[3] Binanto. I. (2010). Multimedia Digital, Dasar Teori dan Pengembangannya. Andi : Yogyakarta.

[4] Bimantoro, L. (2011). Visualisasi Rasi Bintang Berbasis Multimedia, Fakultas Sains dan Teknologi, Jakarta

[5] Ghifani Muhammad Al dan luqman Hakim Handoko dan Endang Ahmad Yani, (2015).“Analisis Kinerja Perbakan Syariah Di Indonesia Dan Malaysia Dengan Pendekatan Maqashid Indeks”. Volume 3. No 2.

[6] Maryati sri dan Bambang Eka Purnama (2013). "Pembuatan Vidio Profile Sekolah Menengah Pertama Negeri 4 Polokarto Kabupaten Sukoharjo Dengan Menggunakan Komputer Multimedia”. Volume 5 No 1-2013.

[7] Nengsih Novia, (2015). "Peranan Perbankan Syariah Dalam Mengimlementasikan Keuangan Inklusif Di Indonesia". Volume 14 (2).

[8] Nurdin Ardiansyah, (2013). "Multimedia Flash 8". Jakarta: Sekolah Tinggi Manajemen Informatika Komputer Eresha.

[9] Novaliendry Dony (2013). "Aplikasi Game Geografi Berbasi Multimedia Interaktif (Studi Kasus Siswa Kelas IX SMPN 1 RAO”. Vol. 6 No. 2 September 2013, ISSN : 2086-4981.

[10] Sutopo, Ariesto Hadi. (2003). "Multimedia Interaktif dengan Flash. Graha Ilmu : Yogyakarta.Sofyan, A. F., \&amp; Purwanto, A. (2008). Digital Multimedia. Yogyakarta 